\title{
Revista Alicantina de Estudios Ingleses
}

\section{$\mathrm{n}^{\mathrm{o}} 16$, November 2003}

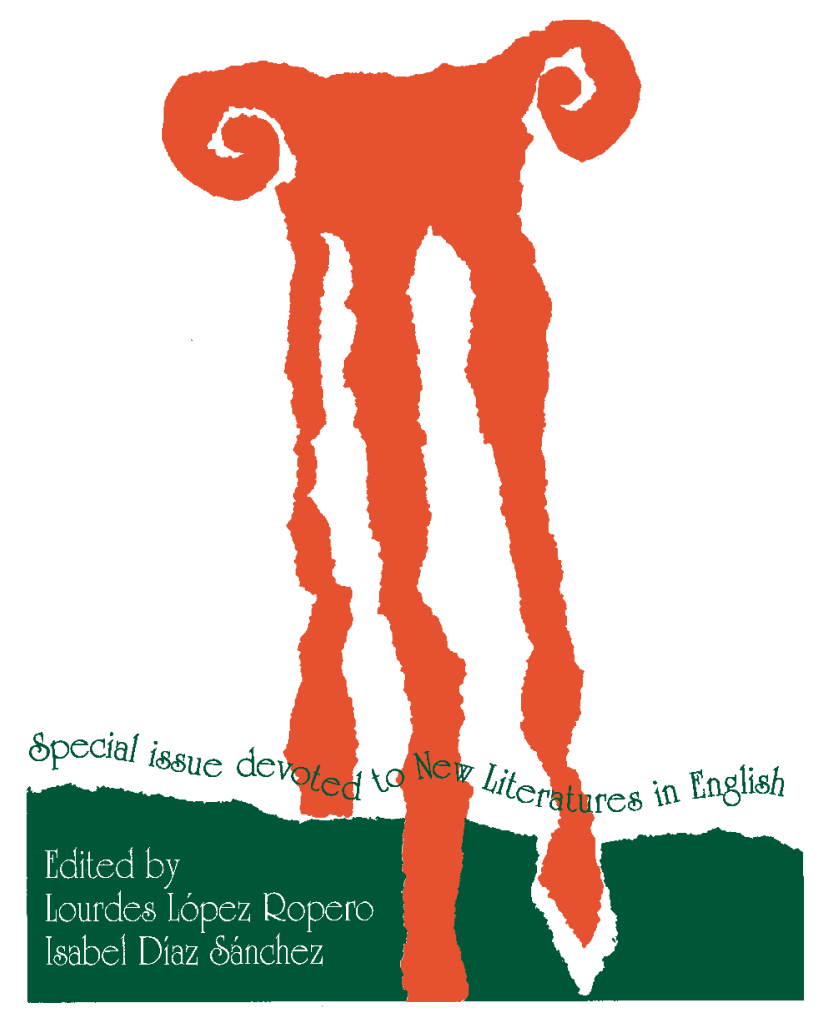

Departamento de Filología Inglesa

Universidad de Alicante 
ISSN 0214-4808 • CODEN RAEIEX

Editor Emeritus

Editors

Editorial Board

Asunción Alba (UNED) • Román Álvarez (University of Salamanca) • Norman F. Blake (University of Sheffield) • Juan de la Cruz (University of Málaga) • Bernd Dietz (University of La Laguna) • Angela Downing (University of Madrid, Complutense) • Francisco Fernández (University of Valencia) • Fernando Galván (University of Alcalá) • Francisco García Tortosa (University of Seville) • Pedro Guardia (University of Barcelona) • Ernst-August Gutt (SIL) • Pilar Hidalgo (University of Málaga) • Ramón López Ortega (University of Extremadura) • Doireann MacDermott (University of Barcelona) • Catalina Montes (University of Salamanca) • Susana Onega (University of Zaragoza) • Esteban Pujals (University of Madrid, Complutense) • Julio C. Santoyo (University of León) • John Sinclair (University of Birmingham)

\section{Advisory Board}

Enrique Alcaraz Varó (University of Alicante) • Manuel Almagro Jiménez (University of Seville) • José Antonio Álvarez Amorós (University of La Coruña) - Antonio Bravo García (University of Oviedo) - Miguel Ángel Campos Pardillos (University of Alicante) • Silvia Caporale (University of Alicante) • José Carnero González (University of Seville) • Fernando Cerezal (University of Alcalá) • Ángeles de la Concha (UNED) • Isabel Díaz Sánchez (University of Alicante) • Teresa Gibert Maceda (UNED) • Teresa Gómez Reus (University of Alicante) • José S. Gómez Soliño (University of La Laguna) • José Manuel González (University of Alicante) • Brian Hughes (University of Alicante) • Antonio Lillo (University of Alicante) • José Mateo Martínez (University of Alicante) • Cynthia Miguélez Giambruno (University of Alicante) • Bryn Moody (University of Alicante) • Ana Isabel Ojea López (University of Oviedo) • Félix Rodríguez González (University of Alicante) • María Socorro Suárez (University of Oviedo) • Justine Tally (University of La Laguna) • Francisco Javier Torres Ribelles (University of Alicante) • M. Carmen África Vidal (University of Salamanca) • Francisco Yus (University of Alicante)

The Revista Alicantina de Estudios Ingleses is published yearly by the Department of English at the University of Alicante in volumes of approximately 250 pages. The journal aims to provide a forum for debate and an outlet for research involving all aspects of English Studies.

NATURE AND FORMAT OF THE ARTICLES: The Revista would welcome articles of the following kinds: (1) Articles on linguistics and ELT, literature, literary theory and criticism, history and other aspects of the culture of the English-speaking nations. Articles should not exceed nine thousand words in length. (2) Bibliographies of studies on very specific topics, providing a brief introduction and a list of basic publications. A concise index of contents may optionally be included. (3) Reviews and review articles on recently published books in the field of English Studies. (4) Poetry translations (English-Spanish and Spanish-English). All articles submitted should follow the guidelines which can be obtained from the following Internet address:

http://www.ua.es/dfing/publicaciones/raei/general/instrucciones.htm 
Manuscripts should include an abstract in English of about one hundred words in length. In normal circumstances, the editors will only consider for publication those contributions written in English and recorded on disk. Two print-outs of the contribution should also be included. Articles will only be returned at the authors' express wish, if so requested at the time of submission. All correspondence should be addressed to:

Revista Alicantina de Estudios Ingleses, Departamento de Filología Inglesa, Universidad de Alicante, P. O. Box 99, E-03080 ALICANTE (Spain)

- ADVERTISING: The journal will be pleased to carry advertisements in either full-page $(17 \times 24 \mathrm{cms}$. approx.) or half-page $(17 \times 12 \mathrm{cms}$. approx.) format. Prices and information are available on request at the above address

- EXCHANGES: The Revista Alicantina de Estudios Ingleses will be happy to make exchange arrangements with similar journals in the same field. All such proposals should be made in writing to the above address

- SUBSCRIPTIONS: The price of subscriptions for FOUR issues of the Revista Alicantina de Estudios Ingleses is as follows: (1) in Spain, $60 €$ for libraries and institutions, and $40 €$ for private subscribers; (2) in countries other than Spain, US $\$ 100$ for libraries and institutions, and US $\$ 67$ for private subscribers. Individual issues for libraries and institutions cost $15 €$ (Spain) or US \$20 (abroad).

Correspondence on subscriptions should be adressed to:

\author{
Marcial Pons Librero \\ San Sotero 6 \\ 28037 MADRID (Spain) \\ revistas@marcialpons.es
}

Portada: Enrique Pérez

Gabinete de Diseño de la Universidad de Alicante

ISSN: 0214-4808

Depósito Legal: A-22-1989

Edición de: COMPOBELL, S.L. Murcia

\title{
Estos créditos pertenecen a la edición impresa de la obra
}

Edición electrónica:

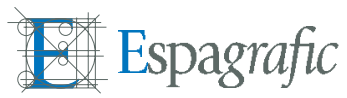




\section{Welsh Writing and Postcoloniality: \\ The Strategic Use of the Blodeuwedd Myth in Emyr Humphreys's Novels \\ Diane Green}


Contents

Welsh Writing and Postcoloniality: The Strategic Use of the Blodeuwedd Myth in Emyr Humphreys's Novels. . . . . . . . . . . . . . . . . . .6 6 Abstract . . . . . . . . . . . . . 6

1. Emyr Humphreys. . . . . . . . . . . . . . . . 11

2. The myth of Blodeuwedd. . . . . . . . . . . 17

3. Dysfunctional families and disabled characters . . . . 23 4. Aranrhod - the virgin mother . . . . . . . . . . . . 32 5. A Matriarchal presentation of Wales . . . . . . . . . 35 Works Cited . . . . . . . . . . . . . . . . . . 40 Notes . . . . . . . . . . . . . . . . . . . . . . 444 


\title{
Welsh Writing and Postcoloniality: The Strategic Use of the Blodeuwedd Myth in Emyr Humphreys's Novels
}

\author{
DIANE GREEN \\ University of Swansea \\ dgreen120@hotmail.com
}

\begin{abstract}
This essay explores ways in which the literature of the nation of Wales may be discussed in postcolonial terms given that it has existed for centuries in an ambiguous position with regard to colonization. Welsh identity is a complex issue, given its intrinsic connections with the Welsh language, which is only spoken by a minority of Welsh people. This essay focuses on the use of indigenous myth as a 'strategy of liberation'. Emyr Humphreys is the major novelist of Welsh writing in English. His novels use myth, particularly Celtic myths, in a wide range of ways. One myth, the story of Blodeuwedd, is used by Humphreys throughout his career. This essay explores the reasons for his use of the myth and the ways it interconnects with the use of disabled
\end{abstract}


Welsh Writing and Postcoloniality: The Strategic Use of the Blodeuwedd Myth in Emyr Humphreys's Novels

Diane Green

characters and dysfunctional families. The advantages of using indigenous myth are balanced against the disadvantages of recalling the past (which is the site of colonization) and presenting women as sinful and disruptive and men as weak, whilst simultaneously promoting a matriarchal society in an attempt to undermine patriarchy/ empire. The essay concludes that the concentrated use of this particular myth is probably counter-productive.

Legends and myths and even fairy tales ... survive the passage of centuries because they contain trace elements of truth about human nature and the human condition. (note 1)

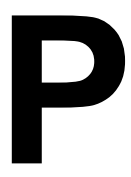

ostcolonial theory has long been interested in the "strategies of liberation" used by writers. These include the mobilisation of indigenous myths as a form of cultural counter-assertion; and the highlighting of "native" social and cultural features that are subversive of the established colonial norm. The authors of The Empire Writes Back argued, in the early days of postcolonial discussion, that: "the seizing of the means of communication and the liberation of post-colonial writing by the appropriation of the written word become crucial features of the process of self-assertion and of the ability to reconstruct the world as an unfolding historical process" (Ashcroft, 1989: 82). In seminal works, such as Achebe's Things Fall Apart, the "strategies of appropriation" (note 2) 


\section{Revista Estudios Ingleses 16 (2003)}

are not merely linguistic, as in the use of 'dialect' to produce an 'english' that is not English, but include cultural strategies, ways of including within the text native customs or manners of behaving, for example, and native discourses from folk-tale and myth. Emerging nations, stemming from colonizers rather than the colonized, adopt similar practices in literature to those of colonized people, such as in the Nigerian novel mentioned above. American literature is also particularly saturated with myth, but with different myths on the whole from those found in the 'mother' literature of Britain. The 'Other' status is privileged and the centre refused by such appropriation. Explorer and settler myths were developed in early American fiction alongside myths of the fall from innocence into experience and of initiation into adulthood. They permeate classic American fiction from Melville and Hawthorne to Twain, and recent novels, such as David Guterson's Snow Falling On Cedars, evoke an American past by re-using both the same myths and alluding to those early novels. However, little attention has been paid to the use of such 'postcolonial' devices in the fiction of British writers who regard their own countries as "internal colonies" (note 3) of an anglocentric state.

For many Welsh writers the creation of a sense of Welsh rather than British identity is an overwhelming concern and this is 
Welsh Writing and Postcoloniality: The Strategic Use of the Blodeuwedd Myth in Emyr Humphreys's Novels

Diane Green

not necessarily tied to the use of the Welsh language. Welsh writers may be bilingual or monoglot English, they may write in Welsh, English or in both languages, and many choose to define themselves in opposition to an idea of Englishness, whether this is represented by the British Establishment, the city of London, the traditional canon of literature or stereotypical English characters. Indeed Dominic Head argues that "a sense of national identity in Wales is more commonly predicated on a reaction against Britishness, and the political and cultural dominance it is perceived to represent" (2002: 144). This sense of writing from a colonized position has been evident in literature written in Welsh for more than a century, at least, but amongst Welsh writers in English, established itself first, perhaps, in the 1960s, alongside greater Welsh nationalist political activity and an increasing interest in the language question.

It is only recently, however, that the critical writing on Welsh literature in English has adopted postcolonial stances, which are more usually associated with writing from ex-colonies in the African and Asian continents. Both Nations and Relations (2000) and the 2001-2 edition of the yearbook Welsh Writing in English contain essays discussing a variety of Welsh writers in postcolonial terms. Indeed Stephen Knight, discussing 


\section{Revista Estudios Ingleses 16 (2003)}

Gwyn Thomas, calls him "a colonized person, as the Welsh still are" (2001-2: 32), admitting that he has only used the term post-colonial for the critics, "those now free Indians and West Indians who subtly guide our thoughts on these matters", whilst in another essay M. Wynn Thomas describes "Wales's subaltern relationship to Britain" (2000: 75). (note 4) What is emerging from these explorations is that postcolonial theories may need broadening in order to contain those nations that, like Wales, are in ambiguous positions in relation to colonial powers: in the case of Wales, situated both within and without the centre. Wales, in a similar although not identical way to Scotland and Northern Ireland, is both an individual nation, which may regard itself as having been colonized by England - in a process arguably beginning in the thirteenth century with the militarism of Edward I, further established by the amalgamation encouraged by the Tudor dynasty, and compounded by the industrial movement and the treatment of the Welsh language in the nineteenth century (note 5) - and a joint constituent of Great Britain, one of the world's principal colonizing forces. This essay will be concerned to demonstrate, through an examination of the use of one specific myth in the hands of one novelist, that bringing postcolonial theories to bear on Welsh writing is a profitable exercise, and 
Welsh Writing and Postcoloniality: The Strategic Use of the Blodeuwedd Myth in Emyr Humphreys's Novels

Diane Green

that it may be necessary to rethink the term postcolonial in the light of literatures of countries such as Wales.

\section{Emyr Humphreys}

Shirley Williams told a story about the late Queen Mother at the specially convened sitting of the House of Lords on April $3^{\text {rd }}, 2002$. She described how an old African gentleman waited in line for hours to meet the Queen Mother and when he eventually did, told her in no uncertain terms how he felt: "Ma'am, I hold against England what has been done to my people and will not easily forgive them"'(Daily Telegraph: 4.4.2002). Apparently she replied, in no uncertain terms, that as a Scot she understood absolutely how he felt. Being British is a blanket condition and for many nationality is a malleable concept, easy to adopt or discard at will. At the present time it is fashionable to be de-centred or peripheral, whether this be English regional or Celtic national. This is not the case with Humphreys, whose genuine commitment to the idea of Wales as a nation has been demonstrated over the whole course of his career. Like other leading Welsh writers who use the medium of English, Humphreys suffers a measure of guilt that he writes in English - which he has termed "the language of the oppressor" (note 6) - and arguably it is this conflict that has inspired his best work. It is also the source of the technical strategies 


\section{Revista Estudios Ingleses 16 (2003)}

he uses as counter-measures, the use of Celtic myth and the harking back to the distant past, strategies of liberation that may, in fact, be strategies of fossilization.

Humphreys, who has been publishing novels for more than half a century, virtually all of which concern themselves with what it means to be Welsh, (note 7 ) is one of Wales's most significant writers. His critical writings and 'real-life' activities have shown committed Welsh nationalism alongside abiding interest in the Welsh situation, which he has described as "our condition of political subservience" (2002: 215). The purpose of this essay is to demonstrate how the politico-cultural stance that is so evident in his critical writings becomes inscribed, in his fiction, as narrative strategies that will repay examination in the light of postcolonial criticism. That a native myth may be used as a strategy of liberation has already been outlined. What is interesting about the particular myth under discussion in this essay is that its use involves other typical postcolonial techniques: the use of disablement to represent the effects of colonization, the use of the weak father or dysfunctional family to challenge colonization in its connection with patriarchy, and the feminist portrayal of the female, which again challenges patriarchy. The story of Blodeuwedd, which appears in The Mabinogion, (note 8) features a woman who has been 
Welsh Writing and Postcoloniality: The Strategic Use of the Blodeuwedd Myth in Emyr Humphreys's Novels

Diane Green

created specifically as the object of male desire for a weak, insecure man. The sexual nature for which she is castigated is, paradoxically, a direct result of her creation by a male for a male and as a sexual object. The result is a broken marriage, death and banishment. In Humphreys's hands the myth becomes a tool with which to explore the situation of Wales.

Indeed it is a commonplace that many feminist strategies overlap with those of postcolonial writing, just as it has been pointed out that tropes of the colonized as feminine and subordinate have been prevalent techniques used in written presentations of Empire by the West. (note 9) The sexual woman has been used to represent the 'Other', both as in racially other and as in forbidden aspects of female behaviour: the use of the incarcerated Bertha in Jane Eyre, for example. Indeed Jean Rhys, in her alternative presentation of Bertha in Wide Sargasso Sea, endorses her protagonist's right to express her sexual nature by showing her sexuality developing in response to her husband's behaviour, whilst simultaneously presenting this as one more way in which the European male can exert control over the colonised female. Rhys, in distinguishing between the white colonized female and the black, female ex-slave, Christophine, gives greater personal/ sexual autonomy to the latter, although legally both Antoinette and 


\section{Revista Estudios Ingleses 16 (2003)}

Christophine are at the mercy of male authority. The husband can both personally incarcerate his wife and threaten Christophine with the police, who will do his bidding. Further, whereas Antoinette can escape from the prison-house in Jamaica, she is only fully restrained in England, in the ancestral pile. Rhys is indicating gradations of male power, which are at their greatest when situated in the colonial centre. Humphreys's is a simplistic presentation compared to some other postcolonial texts, in that he is using the sexual female/ Blodeuwedd archetype to discuss nation but not to discuss race or class; but then, as has already been suggested, Humphreys is a writer who, necessarily, is simultaneously within and without the postcolonial centre.

Humphreys has written extensively about myth, particularly Celtic myth, and how and why he makes connections between myth and the history of the Welsh people. In The Taliesin Tradition, for example, he argues that: "Myth-making is a recognised activity among defeated peoples... Properly understood and used it is a most potent weapon in the struggle for survival" (1989b: 227/8). In using Celtic myth he is asserting Welsh identity rather than allowing Wales to be subsumed into English, under the title of British, culture: "The manufacture and proliferation of myth must always be a major creative 
Welsh Writing and Postcoloniality: The Strategic Use of the Blodeuwedd Myth in Emyr Humphreys's Novels

Diane Green

activity among peoples with high expectations reduced by historic forces into what economic historians like to refer to as 'a marginal condition"' (1980/1: 22). Humphreys makes a strong connection between myth and history, concepts that are more often distinguished as either separate or opposite in the dichotomy of false/ true or fiction/ reality. M. Wynn Thomas has explained that: "Humphreys sees the legends native to Wales as being the specific produce, and symbolic record, of Welsh history" (1991: 274) and Humphreys himself has contrasted "the false history of Geoffrey" with "the truth-bearing fiction of the romances of the Mabinogion" (1989b: 13). In using Celtic myth, and especially The Mabinogion, alongside his use of Welsh history, Humphreys is satisfying his teacherly instinct, providing instruction in matters Welsh alongside the entertainment function of fiction, a function with which Achebe is in wholehearted agreement: "The writer cannot be expected to be excused from the task of re-education and regeneration that must be done". (note 10)

This concern to bring Celtic myth to the consciousness of his audience in order, simultaneously, to express archetypal truths about Welsh characters, to show that personal and political relationships and situations constantly recur, and to connect the character of a society and its culture with the myths 


\section{Revista Estudios Ingleses 16 (2003)}

it produced and continually recycles, is one of Humphreys's principal motivations, a role he describes as the "People's Remembrancer" (note 11), a responsibility to "activate a past that most would prefer to forget" (1987: 16). However, this obsession with the past, whilst clearly intended as a positive postcolonial strategy, might equally be perceived as unproductive. Homi K. Bhabha warns:

Fanon recognizes the crucial importance, for subordinated peoples, of asserting their indigenous cultural traditions and retrieving their repressed histories. But he is far too aware of the dangers of the fixity of fetishism of identities within the calcification of colonial cultures to recommend that 'roots' be stuck in the celebratory romance of the past or by homogenizing the history of the present (1994: 9).

Similarly Dominic Head, writing about Humphreys, warns that "the adherence to a sickly tradition imposes a straitjacket upon the present, cutting it off from its possible futures" (2002: 147). He is less than impressed by Humphreys's obsession with the past, preferring "a kind of postnationalism built on reappraised symbols and traditions that implicitly acknowledges the mongrelized nature of most British identities"(118). In recently published conversations Humphreys admits that his ideal solution would be for Wales to be monoglot Welsh speaking and independent of England, although he admits 
Welsh Writing and Postcoloniality: The Strategic Use of the Blodeuwedd Myth in Emyr Humphreys's Novels

Diane Green

this would not be the choice of the Welsh majority (2002: 132). There are, then, significant dangers in relying too heavily on 'strategies of liberation' that only recall a distant past and do not take account of the changing nature of nationality.

The rest of this essay will examine Humphreys's use of the Blodeuwedd myth and the ramifications of that myth when it is used to symbolize the Welsh situation; whether the extensive use of native myth does indeed lead to the 'calcification' of the colonial Welsh culture.

\section{The myth of Blodeuwedd}

The Blodeuwedd myth occurs within "Math Son of Mathonwy", the fourth branch of the Mabinogi. Central to this branch is the tale of Lleu Llaw Gyffes, "a small something" (Jones: 63) of a son dropped by Aranrhod, evidence she is not the virgin she claimed to be. Snatched up and hidden by the mother's brother, Gwydion, Lleu is reared by his uncle in defiance of Aranrhod, who sees the child as evidence of her shame. She denies him a name, arms and a wife, but Gwydion manages to trick her into supplying the name and arms. He then personally creates out of flowers a wife for Lleu and names her Blodeuedd - the woman made of flowers. Lleu is precocious in size and beauty and born of a supposed virgin. In some respects, then, he is a Christ figure and Blodeuedd becomes the woman missing 


\section{Revista Estudios Ingleses 16 (2003)}

from the Gospel story, a mixture of Mary Magdalene and Eve, the woman made for man. (note 12) Blodeuedd has no say in who should be her husband but when her husband is absent she begins an affair with Gronw Bebyr, who persuades her to find out how her husband may be killed. Under the pretence of concern she extracts from Lleu the complicated procedure by which he may be killed and, once Gronw has prepared what is necessary, she manipulates her husband into enacting the situation so that the lover may strike. Lleu is transformed into an eagle at the point of death and Gronw takes over his kingdom. Gwydion comes to the rescue again, finds and restores Lleu and then marches upon Gronw and Blodeuedd. Gronw is killed by Lleu in exactly the situation in which he, Gronw, threw a spear at Lleu, but Gronw is allowed to place a stone in the way, due to his claim that he acted because of "a woman's wiles"(Jones: 74). (note 13) Blodeuedd is not killed but transformed into an owl, so effectively banished, losing all her female companions and destined to live in enmity and isolation. Her name is changed at this point to Blodeuwedd, meaning 'face of flowers'. (note 14)

This story of Blodeuwedd is one of the most often retold/ reused tales from The Mabinogion. In recent years it has lent itself to 'revisionist myth-making'; Gillian Clarke's poem "Blo- 
Welsh Writing and Postcoloniality: The Strategic Use of the Blodeuwedd Myth in Emyr Humphreys's Novels

Diane Green

deuwedd" in which "the owl follows/ her shadow like a cross/ over the fields"(29) springs to mind. It has also been appropriated by the English writer Alan Garner in his novel for children, The Owl Service. However, Saunders Lewis, who has been, undoubtedly, an important influence on the career of Emyr Humphreys, published his classic play Blodeuwedd, in which his protagonist is treated sympathetically as the victim of fate and sexual passion, as long ago as 1948. (note 15) In the introductory novel to The Land of the Living sequence, National Winner, Humphreys has one of his characters retell the myth, connecting the sexual triangle in it both to the teller, Peredur, and to his parents, Amy and Cilydd, the protagonists of the sequence. This makes the myth unusual in the fiction of Humphreys, in its being deliberately and fully recounted and explicitly related to the modern day characters as a form of redaction (Thomas, 1991: 264-281). In a representative reading of the sequence Amy and Cilydd together represent the people of Wales, just as separately they are, respectively, the Anglicized and the fervently nationalistic elements of Welsh society. (note 16) Overlaying their relationship with the archetype of the Blodeuwedd myth suggests this myth has a particular significance for the fate of Wales, and, however slight or detailed the interpretation, it is inevitable that the fate of both characters, and therefore of Wales, will be miserable. 


\section{Revista Estudios Ingleses 16 (2003)}

Indeed, one of the most intriguing patterns to emerge from a reading of Emyr Humphreys's novels is the regularity of the use of the Blodeuwedd myth as mythological prefiguration, motif or glancing reference. A second intriguing pattern that proves dominant in the novels overall is that each novel usually comprises some or all of the following family figures/ relationships: the bad mother, the weak or absent father, the wayward but dynamic daughter, and the absent or damaged son. What is particularly interesting about this second pattern is that, whilst it relates directly to the Blodeuwedd myth and therefore to the use of Celtic myth, it also undermines the nuclear family and patriarchal society. Both of these traits are ways of undermining empire and criticizing both British rule and canonical English literature. Similarly, the presentation of the dysfunctional family and/or the ineffectual father alongside strong female characters is a way of criticizing or asserting difference to the established colonial/ British ideal. Further, through the importance in Celtic myth of the strong female character and the links with the notion of the Mother Goddess, the two traits clearly work hand in glove for the Welsh writer seeking to assert national identity in the face of the British norm, particularly if that difference has to be expressed through the medium of the English language. 
Welsh Writing and Postcoloniality: The Strategic Use of the Blodeuwedd Myth in Emyr Humphreys's Novels

Diane Green

In a critical text long accepted as a standard study of the origins of the British novel lan Watt describes the model heroine:

The model heroine must be very young, very inexperienced, and so delicate in physical and mental constitution that she faints at any sexual advance; essentially passive, she is devoid of any feelings towards her admirer until the marriage knot is tied - such is Pamela and such are most of the heroines of fiction until the end of the Victorian period (1963: 167).

This description of the typical heroine is clearly very different from Humphreys's principal female characters, even in the early novels, where they are rarely the central character. They may be young and inexperienced, but from the first published novel Humphreys's females are passionate and sexually active, which would appear to be a dominant facet in his interpretation of the Blodeuwedd character. From the beginning of the author's career he focuses upon the triangular relationship, always containing two males, and the sexually active female, rather than the chaste and passive heroine typical of Victorian fiction. This may be connected to the character of Humphreys's mother. In an essay on Outside the House of Baal M. Wynn Thomas writes: "Like Lydia in the novel, Emyr Humphreys's mother was in her youth a free spirit, lively, strongwilled and unconventional, who eagerly embraced marriage 


\section{Revista Estudios Ingleses 16 (2003)}

to a schoolmaster as a convenient escape from a claustrophobic home background" (1998: 122). Humphreys himself describes her (in relation to his father) as "much younger, and much stronger physically, and a very headstrong, impulsive woman". (note 17)

Another aspect of the promiscuous female in the context of postcolonial strategies is that it can be considered a positive symbolic presentation of Wales, because of links with figures such as the Celtic mother goddess, figures redolent of fertility and female dominance. However, the chaste or virginal daughter is seen theoretically as a product of patriarchal societies with their emphasis on the faithful and subservient female, daughter and wife. Further, in social systems such as that in England, where property law is based upon primogeniture, the virgin bride has always been an important instrument in ensuring that a man knows his male heir is his own son. This is, in turn, inextricably interconnected with the high status of the Virgin Mary and the emphasis on chastity in the Christian religion. Any focussing, therefore, on the sensual or non-chaste female is simultaneously expressing negative criticism of Christianity and of patriarchy, the twin staples of English society, and endorsing both the Celtic goddess and the system of savelkind, the Welsh alternative to primogeni- 
Welsh Writing and Postcoloniality: The Strategic Use of the Blodeuwedd Myth in Emyr Humphreys's Novels

Diane Green

ture. It is doubly possible then to see this favourite character of Humphreys as being much more than a psychological construct (whether personal sexual fantasy or Oedipal recreation of the mother); in postcolonial terms it is a disruptive device.

\section{Dysfunctional families and disabled characters}

Ato Quayson has explored the concept of "the tropes of disability" in postcolonial writing (1991: 53-68), in which "wholeness" may be seen as representing the colonizing nation and a disablement, usually physical, as featuring in the central colonized character in a strategy of representation. Many of the novels of the South African J.M. Coetzee employ this trope extremely successfully: in Foe, for example, the tongueless Friday represents the colonized everywhere, the eponymous Michael $\mathrm{K}$ is disfigured and the colonised in Waiting For The Barbarians are represented by the crippled barbarian girl. These characters reflect a range of ideas but the most basic is the enormous handicap under which people in such political situations exist. The colonizing process in Wales happened earlier, historically, than in most of those countries, whose literatures are usually discussed as postcolonial, (note 18) and Wales, as a constituent part of Great Britain, has undoubtedly been in the position of colonizer more recently; nevertheless the attitudes to the English nation and the English language, as expressed 


\section{Revista Estudios Ingleses 16 (2003)}

in Humphreys's numerous critical works, hold a similar political standpoint. It is interesting, then, that Humphreys's Welsh protagonists seem to be similarly, if less drastically, marked by disablement, although this is usually by emotional disablement. This emotional disablement is frequently the result of existing in a dysfunctional family and nowhere is there a more dysfunctional family than in the story of Blodeuwedd.

In Humphreys's early novels the family is usually a scene of strife and the mother the dominant figure. The author is, consciously or unconsciously at this stage, presenting an overturned patriarchy in the family as the microcosm of the colonized or postcolonial society. From the 1970s onwards Humphreys is more deliberately and self-consciously writing about the state of Wales through his fiction and it is therefore no accident, presumably, that the protagonist is now more often female, given the tradition that exists of representing nations as female figures. The ambitious Land of the Living sequence is a prime example. (note 19) The two main characters, Amy and Cilydd, who, for a considerable part of the sequence, are married to each other, together represent the origins and development of the twin cultures of Wales, the one Englishspeaking, the other Welsh. Cilydd is an orphan and his world is dominated by a grandmother who rules the family as well 
Welsh Writing and Postcoloniality: The Strategic Use of the Blodeuwedd Myth in Emyr Humphreys's Novels

Diane Green

as the local community. Amy is also a virtual orphan, with a dead mother and a missing father from unstable stock. She is brought up by her aunt and the aunt's husband, a dominating male, but one who is doubly disabled, both by a quarrying accident and by the massive chip on his shoulder, disablements that correspond with Quayson's theory. The beautiful Amy, who is one of the most obvious Blodeuwedd figures in Humphreys's fiction, (note 20) develops her dynamic personality, promiscuous sexuality and marital cruelty either in defiance of the miserable, patriarchal, Calvinistic uncle or through genes inherited from her beautiful mother and irresponsible father. The second generation, Amy's children, are similarly affected by the dysfunctional relationship between Amy and Cilydd, and Cilydd's increasing isolation within the family unit, which results from Amy's Blodeuwedd-like need to move on to other lovers and her unsuitability to be the wife of "Chilly-feet". The other female characters in the sequence frequently similarly fit the Blodeuwedd pattern; the males, too, are either Lleus or Gronws:

The detailed telling of the myth by Peredur to Maxine, his temporary girlfriend, in National Winner (1971) (note 21) suggests other links are being made by Humphreys. Peredur is on a mission, to research his dead father's past and to intro- 


\section{Revista Estudios Ingleses 16 (2003)}

duce Maxine to his background. It is significant that it is the Welsh landscape, a particular rock, which instigates the telling of the myth, the rock behind which Gronw hid, waiting to kill Lleu. Peredur tells the legend as though it is family history, and he tells it with more familiarity than he could explain his own past, much of which he is in ignorance. Linking myth with real local landscape is something Humphreys himself did as a child, something which has informed his creative life. But Peredur's insight into the myth and his warped understanding of his mother and father urge the reader to question whether or not the portrayal of Cilydd and Amy as Lleu and Blodeuwedd is being shown to us as subconscious manipulation of events. Is the past mis-remembered because of familiarity with set-patterns of story-telling such as myths, or is there some magical connection between a nation's history and the indigenous myths that were a backdrop to the conscious lives of its citizens? Is the historically representative Amy written as Blodeuwedd because myth and history fit together almost seamlessly or is she represented as such because the Welsh nationalist author delights in the myth? Indeed, are Humphreys's female protagonists all Blodeuwedds because of his fascination with the story, or does his fascination with the myth stem from his experience of the female character? 
Welsh Writing and Postcoloniality: The Strategic Use of the Blodeuwedd Myth in Emyr Humphreys's Novels

Diane Green

In his more recent novels the most intense examination has been into the Lleu character, and these are men destined to disintegrate, to be re-formed, to lose their wives - to be "an ice cold man doomed by his mother to live without power and without love" (1971: 43). The female (Blodeuwedd) characters are the lynchpins of the action and it is their behaviour which is analysed, but the reflections/ introspection are centred on the male (Lleu) character, who is middle-aged, sexually frustrated, cynical and disillusioned. These characters are, in effect, an imaginative continuation of the Cilydd character, who, in the sequence, dies relatively young. The Gronw character may experience passion but he is doomed to a troubled conscience and a violent death. With Blodeuwedd forced to live out her life in isolation and darkness, this sexual triangle that pervades Humphreys's fiction is necessarily going to result in pessimistic novels and a defeatist portrayal of Wales.

Simultaneously over the last three decades Humphreys has produced a string of novels independent of the sequence but still focussed in their separate ways on the situation of Wales. Blodeuwedd runs as a motif throughout this work. Unconditional Surrender (1996), Humphreys's penultimate novel so far and one of his finest achievements, is centrally structured by the Blodeuwedd archetype and riddled with its pattern. As 


\section{Revista Estudios Ingleses 16 (2003)}

with several of his more successful novels this mythological patterning works alongside a more obvious history-based chronology, the history here of Wales in 1945. Meg Pritchard, the central character in a tale told half by her father and half by a German countess, Cecilia von Leiten, re-enacts the Blodeuwedd story with greater accuracy of detail than in most of the earlier presentations. Her long-time attachment to a local pacifist, Griff, is destroyed by her passion for a German prisoner-of-war, Klaus. When Griff spears Klaus with a pitchfork the author suggests that Griff is trapped in a pattern of behaviour: "He was locked in his torment and we could do nothing about it" (1996: 116). Klaus treats the situation lightheartedly: "I have come unscratched through the war in order to be speared by a mad pacifist!" (121). The use of the word speared evokes the poisoned spear Gronw labours for a year to make and with which he injures Lleu as well as the spear with which Lleu kills Gronw in revenge. The Rector refers to "the alarming transformations that were taking place" (122), both suggesting that this 1945 situation becomes transformed into the mythic archetype and connecting with the transformation of Blodeuwedd into the owl, an entrapment that may connect with the fact that Meg is pregnant with Klaus's child. 
Welsh Writing and Postcoloniality: The Strategic Use of the Blodeuwedd Myth in Emyr Humphreys's Novels

Diane Green

Meg is typical of Humphreys's heroines: spirited, beautiful, sexually active rather than promiscuous, and driven by moral imperatives. In this presentation Humphreys surrounds her with Blodeuwedd imagery, as she flies about like a bird on her bicycle "as if it were her mission in life to proclaim the birth of freedom" (10) and "glides through the magical transformations of early May knowing how to renew everything"(7) in the opening pages of the novel, establishing his archetype with unusual speed. However, the novel never seeks to analyse Meg's motivation in transferring her affections; spirited and unfaithful appear to have become synonymous in the mind of the author. Any self-analysis in the novel belongs either to the weak father, who is treated throughout as a barely necessary irritation, or to the German Countess, who has also, we eventually find, transferred her affections. Hidden in the opening pages are the clues to the Countess's Blodeuwedd characteristics; she is a "decayed" gentlewoman, who has been married twice (10), and is "trapped in this institution like a moulting bird in an iron cage"(7). Even more surprisingly, the novel traces Meg's mother's transformation from bustling, life-enhancing Rector's wife to a woman ready to leave her ineffectual, principled husband for the nauseating, semi-ridiculous Colonel Bacon; another Blodeuwedd situation. The fighting this time, however, takes place parodically on the chess 


\section{Revista Estudios Ingleses 16 (2003)}

board. The characters of this small Welsh community present the problems that beset Wales in 1945, problems symbolized by the dichotomy of friendship/ hostility with Germany, England's enemy, and in interweaving them so absolutely with the Blodeuwedd myth, and indeed presenting the three nations - England, Wales and Germany - as another aspect of the Blodeuwedd triangle, Humphreys reinforces the use he made of the myth in the sequence and establishes it as an exposition of the Welsh situation.

In all of the later novels the emphasis has shifted as the author has grown older and is now on the ineffectual fathers, who had minor roles in the early novels, as male protagonists. These later novels, however, have in common that the weak father is also the rejected husband, the Lleu role, and it is the psychology of these characters that interests Humphreys and that has become the predominant tool for his exploration of the subject of Wales. Blodeuwedd still represents the resurgent, hopeful aspect of Welsh matters but this role is now overshadowed by that played by the ineffectual male. The same alteration of balance may be seen if one considers the final volume of The Land of the Living sequence, Bonds of Attachment, with its increased emphasis on the character of Cilydd. Humphreys has been unable to sustain his female presenta- 
Welsh Writing and Postcoloniality: The Strategic Use of the Blodeuwedd Myth in Emyr Humphreys's Novels

Diane Green

tion of the nation and has reverted to the use of the disabled male, which may have connections with Wales's unusual position as an "internal colony" of Britain, referred to earlier. The very complex relationship that exists between the Welsh and English nations - the fact, for example, that Wales would be considered as a constituent part of the 'centre' in the eyes of many postcolonial writers writing against that 'centre' - may be connected to this use of male emotional rather than physical disablement. The handicap Humphreys's characters have is principally self-perceived and might negatively be termed 'an inferiority complex' or more positively perceived as 'sensitivity'. (note 22) They are all academic high-achievers, materially they are comfortably situated, but sexually they are frustrated or impotent and they are either childless or lose their children, whether actually or metaphorically. Like Lleu, when Gwydion finds him in the myth as an eagle near to death with pigs feeding on the rotting flesh and worms as they fall from him, these men are skin and bone only and they do not have the magic of Gwydion to restore them.

In all of his detailed presentations of the Blodeuwedd archetype, Humphreys presents the female Blodeuwedds as having potential, if only they were able to step out of the tragic pattern and not repeat the past. However, Lleu not Gronw is 


\section{Revista Estudios Ingleses 16 (2003)}

his chosen representation of Wales through the male character, and Lleu is always emotionally disabled by his mother's rejection. Aranrhod, mother of Lleu, has a lot to answer for in this depiction of Wales, without name, without weapons, without wife - unless one wishes to focus on a Wales conquered in a military sense by Edward I and further damaged by legislation against the Welsh Language - and if we trace the first motivation in the myth, Aranrhod's problems stem from two things: the male king's need to rest his feet in the lap of a virgin, and the fact that Aranrhod wasn't one, although she was beautiful.

\section{Aranrhod - the virgin mother}

The myth of Blodeuwedd begins with a particular situation that will bear investigation: "at that time Math son of Mathonwy might not live save his two feet were in the fold of a maiden's lap" (Jones: 55). This suggests that the nation will founder unless there is complete patriarchal control of female chastity. Aranrhod, who is put forward as a suitable candidate for this position of maiden, produces two sons when her virginity is tested by the king. One of these is tiny and only noticed by Gwydion, her brother, who raises it in secrecy as his own son. This introduces implications of incest, and also of male mothering, either of which produces an unnaturally large and 
Welsh Writing and Postcoloniality: The Strategic Use of the Blodeuwedd Myth in Emyr Humphreys's Novels

Diane Green

beautiful child, who is nevertheless cursed by his mother when she discovers his existence. In a male presentation of this story Aranrhod can seem vindictive and unnatural; however, a female presentation would see the denial of Lleu's right to name, arms or wife as an attempt to limit the power of patriarchy, which depends on the perpetuation of the male name, on the power of force and on the begetting of legitimate heirs. The Blodeuwedd myth makes explicit that the story hinges on the king's emphasis on his right to female virginity. Shamed and rejected, Aranrhod then represents the subjugated 'other' to the patriarchal male. Her actions against Lleu are her way of attacking the male power that has disgraced her. In this Aranrhod herself represents Wales in the relationship of 'internal colony' of England, a scenario that produces Lleu and Blodeuwedd, the weak betrayed male and the unfaithful selfcentred woman, as the end result of a colonised situation that resists or challenges the controlling power.

If we shift the focus of representing the nation onto Aranrhod rather than Blodeuwedd, an important aspect of the myth emerges that has so far remained undiscussed. Blodeuwedd might represent the individual without a past, a history, and without a family network, which would in turn entail a system of social and moral values. In her failure to exist in these 


\section{Revista Estudios Ingleses 16 (2003)}

circumstances aligned with the failure of Lleu's marriage to a woman outside his social nexus, the myth may be used, firstly, to warn of the dangers inherent in marriage outside the community and, secondly, to emphasize the difficulties faced by a nation that resists the patriarchal system in order to resist empire. Aranrhod's attempt to end male control as a paradigm for defeating empire has resulted in the denial of the safe nuclear family to her son and therefore to the future Welsh nation.

Within Humphreys's novels many of the female figures recall this aspect of Blodeuwedd. Amy Parry, perhaps the most significant of these characters, is an orphan and, although she has a close-knit adoptive family, it is the manner in which she is raised, the poverty, hardship and resentment, that is a major cause of her actions as an adult, including her treatment of her husband. Enough of Humphreys's Blodeuwedds fit the pattern to suggest that the character's alienation or isolation from cultural norms is an important element of the archetype. However, the presentation of Blodeuwedd in The Mabinogion is ambiguous; she is treacherous to her husband but she was created by Gwydion, a male, for his adopted son and therefore a male made her that way. Further, her love for Gronw is instinctive: "the moment she looked there was 
Welsh Writing and Postcoloniality: The Strategic Use of the Blodeuwedd Myth in Emyr Humphreys's Novels

Diane Green

no part of her that was not filled with love of him" (Jones: 69) and, in her defence, she had no say in her marriage to Lleu. Humphreys retains the same ambiguity; his novels present female characters with great sympathy yet simultaneously show them wreaking enormous havoc, often in proportion to their great beauty. Blodeuwedd was of course "the fairest and best endowed maiden that mortal ever saw" (Jones: 68). For the majority of the sequence Amy is the central character and the 'dramatic episodes' presented by Humphreys work to explain her motivation. It is only at the end of the sequence that the reader is encouraged to question both his/her own understanding of and to realize the extent to which Cilydd has been damaged by her and misjudged by others.

\section{A Matriarchal presentation of Wales}

The use of the matriarchal or matrilineal model of society in an undermining of patriarchy or empire is another strategy of liberation. (note 23) Its use as a feminist device in Jane Eyre is a useful illustration of how it can work to disrupt the patriarchal status quo. All of Jane's problems stem firstly, from the death of the uncle who preferred her, his sister's child, his matrilineal heir to his own children, and secondly, from her aunt's insistence on the patriarchal rights of the nuclear family, on the superiority of the Reed children and the exclusion 


\section{Revista Estudios Ingleses 16 (2003)}

of Jane. Whilst Aunt Reed's nuclear family gradually disintegrates around her and culminates in the death of both the aunt and the bully, John Reed, Jane's personal development requires her involvement in pseudo-families built around caring women, Miss Temple and then Mrs Fairfax, and avoiding damaging and false patriarchs. Further, when Jane's paternal uncle dies making her his heir rather than the children of his sister - the Rivers family - Jane gives three quarters of her inheritance to these new cousins, affirming the equal right to inherit of the matrilineal line. Indeed the ending of the novel suggests that Jane Eyre's son will be raised in contact with his mother's relatives, with no suggestion of any contact with any Rochesters.

Humphreys uses similar techniques in The Land of the Living sequence. Not only is Cilydd's background matriarchal, ruled by his indomitable grandmother, but Amy is brought up by her mother's sister and becomes the centre of a female community wherever she finds herself living. However, unlike Bronte, Humphreys presents matriarchy as sterile and stultifying, damaging to the nuclear family. Cilydd, oppressed by his relationship with his neurotic sister, opts for marriage, first with Enid, then with Amy. It is the only natural child of this second marriage, Peredur, who, unattractive and undersized, 
Welsh Writing and Postcoloniality: The Strategic Use of the Blodeuwedd Myth in Emyr Humphreys's Novels

Diane Green

reminds the reader of "the small something" dropped and rejected by Aranrhod, not least in that he is resented by Amy as the cause of her not becoming a Labour M.P. Peredur, then, is Lleu not only because of the way his girlfriends treat him, but also in his origins. And on the representative level he is the only child of the two characters who represent the two constituent parts of the Welsh nation. Lleu, or Peredur, is, therefore, in a representative reading, the present and future of Wales.

Humphreys has said that the central figure in his sequence "had to be a woman" (Smith, 1988: 9) and in the same interview he outlines the importance of women in the Welsh experience -"she's central, she's continuity, she's survival" (ibid.)but Blodeuwedd is not a version of the Celtic Goddess; she's fallible and childless, the Welsh mixture of Eve and Mary Magdalene, man's construction of an eternal scapegoat for the ills of patriarchy. The Blodeuwedd myth, therefore, does serve to castigate patriarchal power/ empire and does represent the subordinate - subaltern - situation, in which some Welsh people may feel they exist/ed. However, it shows the damage done by reaction against the centre of power. It implies that a return to undamaged patriarchy is required - the kingdom of Math before he shamed Aranrhod - but, since we 


\section{Revista Estudios Ingleses 16 (2003)}

are equating patriarchy with the colonial centre, this would entail complete sublimation into that centre - identification with England. What the myth does not offer is the possibility of a new, positive position; instead it ends with the dissatisfaction/ de-masculation of Lleu and the exile of Blodeuwedd. Indeed, Humphreys's work is riddled with the dichotomy that the Welsh nation should learn from the past/ history but that the past/ myth will be endlessly repeated. He has famously stated that for the Welsh history and myth are inextricably linked: "For the Welsh to distinguish between myth and history has always been a difficult exercise" (1989b: 13). He believes that the Welsh people need to know their past in order to assert their identity as a nation, yet this knowledge appears to hold a defeatist purpose: "to convince a beleaguered remnant that they are a fragment of humanity scheduled, in spite of everything, for ultimate preservation" (1989b: 229).

Where does this leave the postcolonialist Welshman? We have seen that Humphreys's novels, with their weak fathers and damaged families, portray patriarchy as destructive and ultimately ineffectual, and the colonized position as disabled, miserable and frustrated. It is, of course, inevitable, if the dysfunctional family is used as a postcolonial device, that the nation or situation symbolized by the representation, in being 
Welsh Writing and Postcoloniality: The Strategic Use of the Blodeuwedd Myth in Emyr Humphreys's Novels

Diane Green

presented as fractured, disparate or ineffectual, will appear in a negative light, when what may be intended is the portrayal of difference. In the association of the perfect nuclear family with patriarchy and of patriarchy with empire and colonization, problems of implication from the symbols used and also from the language in which they are being expressed are inevitable. Through much of his career Humphreys presents the young vivacious Blodeuwedd as an assertion of rebellious nationhood but the words girl, woman and wife situated in the mid-twentieth century inevitably have connotations of inferiority. The outstanding images for the reader are of Meg on her bicycle and Amy smashing the Golf Club window. These females are not 'Pamelas', they are not prone to fainting but, if they portray Wales, it is a Wales that is undaunted but nevertheless the inferior partner in a marriage. The weakness inherent in this use of Blodeuwedd as a post-colonial strategy is that she was made for male enjoyment rather than to exist on her own; without patriarchy - colonization - then, it is questionable whether she, or this view of Wales, would exist. 


\section{Revista Estudios Ingleses 16 (2003)}

\section{Works Cited}

Achebe, Chinua (1958): Things Fall Apart. Oxford: Heinemann.

Ashcroft, Bill, Gareth Griffiths and Helen Tiffin (1989): The Empire Writes Back: theory and practice in post-colonial literatures. London: Routledge.

Bhabha, Homi K (1994): The Location of Culture. London: Routledge. Bronte, Charlotte (1987): Jane Eyre. Ed. Richard J. Dunn. New York: Norton.

Brown, Tony and Russell Stephens, Eds. (2000): Nations and Relations: Writing Across the Bristish Isles. Cardiff: New Welsh Review.

Clarke, Gillian (1982): "Blodeuwedd". Letter from a Far Country. Manchester: Carcarnet, 29.

Coetzee, J.M. (1986): Foe. London: Penguin.

- (1998): Waiting for the Barbarians. London: Vintage.

- (1998): The Life and Times of Michael K. London: Vintage

Frazier, Charles (1997): Cold Mountain. London: Hodder \& Stoughton.

Garner, Alan (1981): The Owl Service. London: Fontana.

Green, Diane (2001/2): "From Pig-sty to Benin Head: Modernism and Postcolonialism in Emyr Humphreys's Jones". Welsh Writing in English: A Yearbook of Critical Essays. 7: 35-49. 


\section{Welsh Writing and Postcoloniality: The Strategic Use of the Blodeuwedd Myth in Emyr Humphreys's Novels Diane Green}

Guterson, David (1995): Snow Falling on Cedars. London: Bloomsbury.

Head, Dominic (2002): Modern British Fiction, 1950-2000. Cambridge: Cambridge University Press.

Hechter, Michael (1975): Internal Colonialism. London: Routledge. Hooker, Jeremy (2001): "Emyr Humphreys's Bonds of Attachment". Imagining Wales. Cardiff: UWP.

Humphreys, Emyr - novels:

- (1946): The Little Kingdom. London: Eyre and Spottiswoode.

- (1949): The Voice of A Stranger. London: Eyre and Spottiswoode.

- (1951): A Change of Heart. London: Eyre and Spottiswoode.

- (1952): Hear and Forgive. London: Victor Gollancz.

- (1957) The Italian Wife. London: Eyre and Spottiswoode.

-(1958) A Toy Epic. London; Eyre and Spottiswoode (and Bridgend: Seren, 1989).

— (1963) The Gift. London: Eyre and Spottiswoode.

- (1965) Outside the House of Baal. London: Eyre and Spottiswoode (and Bridgend: Seren, 1995).

- (1971) National Winner. London: Macdonald.

- (1974) Flesh and Blood. London: Hodder and Stoughton.

- (1978) The Best of Friends. London: Hodder and Stoughton

- (1980) The Anchor Tree. London: Hodder and Stoughton. 


\section{Revista Estudios Ingleses 16 (2003)}

- (1984) Jones. London: Dent.

- (1985) Salt of the Earth. London: Dent.

- (1988) An Absolute Hero. London: Dent, 1986 and Sphere.

- (1989a) Open Secrets. London: Dent, 1988. and Sphere.

- (1991) Bonds of Attachment. London: Macdonald, 1991 and Sphere.

— (1996) Unconditional Surrender. Bridgend : Seren.

— (1998) The Gift of a Daughter. Bridgend : Seren, 1998.

Critical writing:

-(1980/1): "A Perpetual Curate". Powys Review 8: 22-27.

- (1987): "The Third Difficulty", Planet 61, Feb. March 1987. Reprinted in (2002) Emyr Humphreys: Conversations and Reflection. Cardiff: UWP, 200-210.

- (1989b): The Taliesin Tradition. Bridgend: Seren.

- (2001): "The Empty Space: Creating a Novel". North American Journal of Welsh Studies. Vol. 1(1). Reprinted in (2002):Emyr Humphreys: Conversations and Reflections. Cardiff: UWP, 211-223.

- (2002): Emyr Humphreys: Conversations and Reflections. Ed. by M. Wynn Thomas. Cardiff: UWP.

Jones, Gwyn and Thomas Jones. Eds. (1989): The Mabinogion. London: Dent. 
Knight, Stephen (2001/2): “The Voices of Glamorgan: Gwyn Thomas's Colonial Fiction". Welsh Writing in English: A Yearbook of Critical Essays. 7: 16-34.

Quayson. Ato (1991): "Looking Awry: Tropes of Disability in Post-colonial Writing". An Introduction to Contemporary Fiction: International Writing in English since 1970. Ed. Rod Mengham. Cambridge: Polity Press, 53-68.

- (2000): "Feminism and Modernity". Postcolonialism: Theory, Practice or Process? Cambridge: Polity Press, 103-131.

Rhys, Jean (1968): Wide Sargasso Sea. Harmondsworth: Penguin.

Robichaud, Paul (2001/2): “'It is our duty to sing': Y Gododdin and David Jones's In Parenthesis". Welsh Writing in English: A Yearbook of Critical Essays 7: 1-15.

Smith, Penny (1988): “Interview”. New Welsh Review 2: 4 -11.

Thomas, Gwyn (Trans.) (1983): "Blodeuwedd". Presenting Saunders Lewis, Eds. Alun R. Jones and Gwyn Thomas. Cardiff: UWP, 199250.

Thomas, M.Wynn (1991): "Emyr Humphreys: Mythic Realist", Proceedings of the Third Conference on the Literature of Region and Nation. Eds. J.J. Simon and Alain Simner. Luxemburg: Publications du Centre Universitaire de Luxemburg, 264-281.

- (1998): "Outside the House of Baal: The Evolution of a Major Novel". Seeing Wales Whole. Ed. Sam Adams. Cardiff: University of Wales Press, 121-143.

Watt, lan (1963):The Rise of the Novel. Harmondsworth: Penguin. 


\section{Revista Estudios Ingleses 16 (2003)}

1. Emyr Humphreys, "The Empty Space: Creating a Novel", North American Journal of Welsh Studies, Vol. 1,1 (Winter 2001). Reprinted in Emyr Humphreys: Conversations and Reflections, Ed. by M. Wynn Thomas (Cardiff: UWP, 2002).

2. Strategies of appropriation are defined by Bill Ashcroft as "the process by which language is taken and made to 'bear the burden' of one's own cultural experience" (1989: 38).

3. Michael Hechter introduces the idea of internal colonialism in Internal Colonialism (London: Routledge, 1975) 8. Briefly, he defines the model as one in which "the core is seen to dominate the periphery politically and to exploit it materially" (9).

4. See Stephen Knight, "The Voices of Glamorgan: Gwyn Thomas's Colonial Fiction", Welsh Writing in English yearbook, vol 7 (2001-2) 16-34 and M. Wynn Thomas and Tony Brown, "Colonial Wales and Fractured Language", Nations and Relations, eds. Tony Brown and Russell Stephens (Cardiff: New Welsh Review, 2000). 71-88.

For recent post-colonial approaches see Paul Robichaud's essay on David Jones's In Parenthesis and Diane Green's essay on Emyr Humphreys in the former volume. Also, see essays by Daniel Williams, amongst others, in the latter.

5. Gwyn A. Williams has argued that "the Welsh as a people were born disinherited" (When Was Wales? (Harmondsworth: Penguin, 1985) 45).

6. See "Conversation Three", Conversations where Humphreys says: "When you adopt the language of the oppressor, the imperial power or 
whatever it may be, you are taking part in the oppression. You yourself become guilty. You therefore have this terrible nightmarish conflict, which has been with me all my life in the form of an inner tension" ( $p$. 131).

7. Humphreys has published 20 novels in the period from 1946 to 1998, alongside editions of poetry and short stories and a wide range of factual and critical material, much of which is reproduced in the recent Emyr Humphreys: Conversations and Reflections. He has written The Taliesin Tradition (Bridgend: Seren, 1989) on the history of Wales, has taught at different periods and has worked for a considerable time for the BBC as a producer. He has also provided many dramas in Welsh for S4C.

8. The Mabinogion is the title given by Charlotte Guest to her translation of 12 medieval tales published in the mid-nineteenth century, and which has since established itself as the general name of the collection of Welsh stories/ myths. The tales have not only assumed a central importance in modern Welsh writing but also been recognized as one of the great treasures of European literary culture. Any references to The Mabinogion will be to the Gwyn Jones and Thomas Jones edition (London: Dent, 1989).

9. See, for example, Ato Quayson, Postcolonialism: Theory, Practice or Process? (Cambridge: Polity Press, 2000) 109.

10. From "The novelist as teacher" (Achebe 45) as quoted in Ashcroft et al, 125. 


\section{Revista Estudios Ingleses 16 (2003)}

11. See Humphreys's comments in "The Third Difficulty", Planet 61, Feb. March 1987, 16.

Reprinted in Emyr Humphreys: Conversations and Reflections, Ed. by M. Wynn Thomas (Cardiff: UWP, 2002).

12. As is the case with Blodeuwedd, Eve's story may have a patriarchal or a feminist slant. Milton's version of Eve, for example, puts far more responsibility upon her than does the Genesis version.

13. This is another instance of similarity with the patriarchal Biblical Eve and the Classical Pandora, both of whom are used as ways of blaming the evil in the world on the misplaced sexuality or curiosity of the female.

14. The names Blodeuedd and Blodeuwedd are explained in The Mabinogion, 68 \& 74 .

15. A translation by Gwyn Thomas is included in Presenting Saunders Lewis, Eds. Alun R. Jones and Gwyn Thomas (Cardiff; UWP, 1983) 199-250.

16. This essay will have further cause to refer to the way in which the characters of the sequence may be interpreted as representative figures in a historical reading. The importance of the representative reading can be overstated and it is not the intention of this essay to assert that this is the only or indeed the primary reading. Jeremy Hooker has stated that: "Emyr Humphreys is concerned with his main characters as whole human beings" ("Emyr Humphreys's Bonds of Attachment", 4 ) and demonstrates this very clearly in his chapter. He has also further illuminated the representation: "As an ideal and as a force of na- 
ture Amy is what other men and women desire, and it is in this sense that she may be described as a symbol of Wales" (p. 18).

17. See "Conversation Three", Conversations, 124. Humphreys does here, however, deny that his fictional presentations of strong women are connected to the character of his mother.

18. See the introductory section to this essay, page 3.

19. The Land of the Living sequence comprises seven novels: National Winner (London: Macdonald, 1971), Flesh and Blood (London: Hodder and Stoughton, 1974), The Best of Friends (London: Hodder and Stoughton, 1978), Salt of the Earth (London: Dent, 1985), An Absolute Hero (London: Dent, 1986), Open Secrets (London: Dent, 1988), Bonds of Attachment (London: Macdonald, 1991).

20. It is important to note that Amy is also at times during the sequence of novels not only Blodeuwedd but the Lady of the Fountain and Luned, from that myth, and Guinevere as well as Gwenhwyfar from the Arthur myth. The myths of Arthur, both British and Celtic, are indeed the predominant myths used.

21. National Winner was the first of the seven novels to be written, but when they are read chronologically becomes the sixth novel of the sequence. This recounting of the Blodeuwedd myth was, therefore, produced at a very early stage of the writing.

22. Compare Cilydd, for instance, with Coetzee's blind, crippled beggar-girl in Waiting for the Barbarians, his mutilated Friday in Foe or his facially disfigured Michael K. 
23. See Ato Quayson, "Feminism and Modernity", Postcolonialism: Theory, Practice or Process? (Cambridge: Polity Press, 2000) 103-131 for a discussion on the problems faced by African women in matrilineal societies within postcolonial criticism based on the nuclear family. 